\title{
対象物の色に関する知識が日常的なシーンの 再認記憶に与える影響
}

\author{
川端康弘 \\ (北海道大学文学研究科) \\ 川端美穂 \\ 山本裕基 \\ key wor ds: ビジュアルシーン、再認、物体色、色に関する知識
}

記憶した情景に含まれる再認に有効な多くの手がかりの うち、色は空間的広がりが限定された対象よりも大局的な広 がりを持つ対象と結びついて再認記憶に貢献する ( 川端, 2002)。これは知覚的なレベルで、すなわち情景内のある対 象物と他のものと区別するとき視差性の高い特徵として色 コントラストが有効であり、乥れが再認においてもある程度 貢献するのであろう。一方で色は視差性だけではなく対象物 の属性を示すある種の知識としても重要である。自然物の多 くは単色から数色の典型色を持つ場合が多いし、人工物の場 合でも全く無制限に表面色が現れる場合はむしろまれで何 らかの制約がある。つまり現実世界の対象物はどれも色の現 れ方 (分布) にかなりの統計的な偏りがある。この分布の範 囲や偏りを、私たちはあまり意識しないけれども日常生活で の樣々な経験を通して獲得し、物の特徵を表すための知識と して利用している。この実験では川端( 2002) とほぼ同樣のパ ラダイムを用いて、ビジュアルシーンを構成する対象物の色 の再認記憶における色の知識の効果について検討した。

\section{【対象物の色の現れ方に関する調査】}

まず日常世界の中にある対象物の色の現れ方について質問 紙とスクリーン上に投影した色見本を用いて調査を行った。 観察者として北海道大学の学生 119名（男性 71名、女性 47 名) が参加した。対象物として自然物、加工品、人工物の中 から 20 項目（チューリップ、バラ、菜の花、すみれ、バナ ナ、りんご、ぶどう、木の葉、地面、日中の空、海、畑、豆、 お茶、建物の外壁、冷蔵庫、本の表紙、口紅、男性の普段着、 携帯電話、自動車) を選んだ。各対象物に対して 30〜120色 のマンセル色票を準備し、メディアプロジェクターで暗室の スクリーン上に 50 個程度ずつ色票を呈示し、対象の色とし て可能性のある色をすべて選んでもらった。各対象物はとく に画像で示したりはせず言葉で述べるにとどめた。次に選ん だ色が、弚の物の色として実世界の中に出現すると思われる

\begin{tabular}{lcccc} 
表1 & 対象物の色分布 & & & \\
対象物 & 典型色数 & 色相分布 & 明度分布 & 飽和度分布 \\
& 0 & $1-100$ & $1-100$ & $1-100$ \\
\hline & & & & \\
菜の花 & 1 & 4 & 6 & 6 \\
バナナ & 1 & 14 & 14 & 10 \\
りんご & 1 & 23 & 24 & 16 \\
口紅 & 1 & 31 & 48 & 52 \\
木の葉 & 1 & 41 & 51 & 32 \\
日中の空 & 1 & 31 & 67 & 64 \\
冷蔵庫 & 1 & 52 & 12 & 25 \\
海 & 2 & 25 & 54 & 35 \\
チューリップ & 2 & 32 & 19 & 12 \\
バラ & 2 & 37 & 31 & 22 \\
ぶどう & 3 & 29 & 18 & 15 \\
すみれ & 3 & 39 & 26 & 14 \\
お茶 & 3 & 43 & 25 & 24 \\
地面 & 3 & 26 & 32 & 41 \\
畑 & 3 & 25 & 32 & 39 \\
本の表紙 & 3 & 72 & 20 & 32 \\
自動車 & 4 & 54 & 63 & 82 \\
携帯電話 & 0 & 42 & 54 & 32 \\
男性の普段着 & 0 & 65 & 65 & 86 \\
建物の外壁 & 0 & 72 & 26 & 32 \\
\hline
\end{tabular}

割合( \% を全ての色の合計が 100\%こなるように反応してもら つた。各対象物について選択された色票の出現率の平均值を 求めた。20項目の対象物について色の出現分布の特徵を知る ため、以下のような表にまとめた。ここで色相、明度、飽和 度の各分布は、1 力所に分布が集中する場合を 0 、均等に分 布する場合を 100 として数値化したものである。

\section{【色の再認実験】}

刺激はグラフィックカードを搭載した PC( AT 互換)により ディスプレイ上に呈示された（視角で横 $47^{\circ}$ 縦 $34^{\circ}$ )。刺激 は調査対象物のいずれかを含む日常的情景を撮影したデジ タル画像である。実験には21名の被験者が参加した。

実験には計 960 枚の画像が用いられ、各被験者には記銘・ 再認とも計 120 枚の画像が呈示される。記名時の画像に含ま れる対象物の色は、弚の色が本来持つ分布の範囲内であるが、 出現頻度が $20 \%$ 以内の色に調整されている。つまり产の物の 色として違和感は無いが、典型色という程ではない。再認段 階では 120枚中半数の画像内の対象物の色か変更されている。 色の変化は、色相、明度および飽和度の各次元について識別 閾の 2 倍を最小単位として偶数倍で 30 倍までの值を準備し た。被験者の課題は、記銘時の画像と比べて色が変更されて いると思った場合にはYes ボタンを、変わっていないと思っ た場合にはN Noボタンを押すことである。Yes 反応したときに は画像内のどこの色か変わったか口答し、学習段階の色とし てふさわしいものを複数の色票の中から選択してもらった。 再認結果は元の色と視差性が同じ色変化でも、対象物が本来 持つ色の分布に含まれる変化か否かで正答率に大きな違い がある (図 1、バナナの場合)。また学習段階の色として被 験者が挙げたものは、調査で示された対象物の色の分布の範 囲内のものや典型色が多かった。図 2 は自動車の場合だが学 習段階の実際の色 (青緑) を回答した人はいなかった。

(KAWABATA Yasuhi ro, KAMABATA M ho, YAMAMOTO Hi roki )

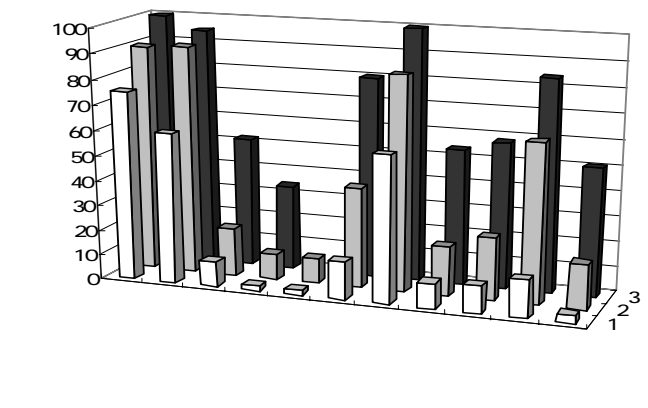

图 1 色变化ごとの正答率。バナナの場合

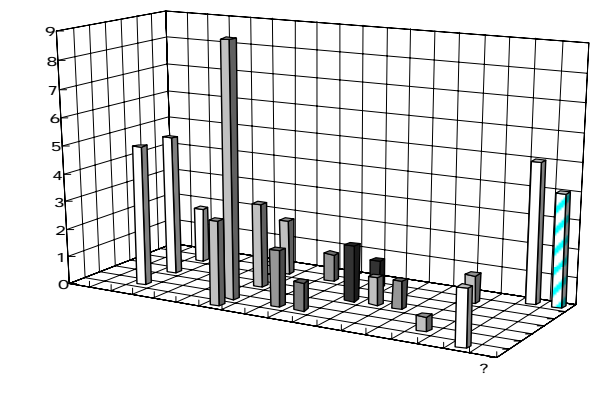

図 2 学習段階の色として回答された数、車の場合 